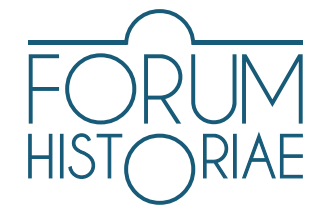

\title{
“'Tis with the Chalice that We'll Defend Our Country against the Cross..." Analysing and Comparing the Contents of the Neo-Nazi Fanzine Skinformátor and the Utraquist Zine Kalich*
}

\author{
Jan Charvát
}

\begin{abstract}
Charvát, Jan: "'Tis with the Chalice that We'll Defend Our Country against the Cross..." Analysing and Comparing the Contents of the Neo-Nazi Fanzine Skinformátor and the Utraquist Zine Kalich.

Fanzines simultaneously reflected the subculture's ideological cleavages, including those within the far-right branch itself (disregarding anti-racist or apolitical fanzines). As the racist skinhead subculture formed in the first half of the 1990s, it split into the more-or-less open neo-Nazis, on the one hand, and the so-called Utraquist skinheads, with their ideological amalgam of nationalism, racism and authoritarianism, on the other. The Utraquist skinhead groups are a unique Czech phenomenon; they have no international counterparts and have thus far received minimal attention. Therefore, the research question follows: In what ways are the publications of a selected neo-Nazi zine (Skinformátor, "The Skin-informer") different from a selected representative of the Utraquist zines (Kalich, "The Chalice")? In the following, I am going to focus on comparing the choice of topics and their elaboration in the two fanzines. It is not the goal of this paper to analyse the different categories of fanzine content in depth. My goal at this research stage is to identify the contrasts between the two fanzines as representatives of different approaches to politicising skinhead subculture in the far-right context.
\end{abstract}

Keywords: skinheads, far-right, fanzines, subculture, neo-Nazism, nationalism

DOI: https://doi.org/10.31577/forhist.2020.14.1.7

$I^{\prime}$ $n$ recent years, the issues of the (not only) the subcultural far-right have become an essential focus of both Czech sociology and political science. After many years of dominance of the perspective of extremism theory, ${ }^{1}$ several works with a different orientation have recently appeared, whether based in sociology ${ }^{2}$ or history ${ }^{3}$ or taking an interdisciplinary approach. ${ }^{4}$ At the same time, there

\footnotetext{
* This paper was supported by the Progress research program of Charles University Q18 - Social sciences: from multidisciplinarity to interdisciplinarity.

1 Extremismus mládeže v České republice. Praha : Institut pro kriminologii a sociální prevenci, 1996; FIALA, Petr. (ed.) Politický extremismus a radikalismus v České republice. Brno : Masaryk University, 1998; MAREŠ, Miroslav. Pravicový extremismus a radikalismus $v \breve{C} R$. Brno : Barrister \& Principal; Centrum strategických studií, 2003; CHARVÁT, Jan. Současný politický extremismus a radikalismus. Praha : Portál, 2007.

2 KOLÁŘOVÁ, Marța (ed) Revolta stylem: Hudební subkultury mládeže ČR. Praha : SLON, 2011; HEŘMANSKÝ, Martin - NOVOTNÁ, Hedvika. Hudební subkultury. In Janeček, Petr (ed.) Folklor atomového věku. Kolektivně sdílené prvky expresivní kultury v soudobé české společnosti. Praha : Národní museum; Fakulta humanitních studií Univerzity Karlovy v Praze, 2011, pp. 89-110; NOVOTNÁ, Hedvika - HEŘMANSKÝ, Martin. Shared Enemies, Shared Friends: the Relational Character of Subcultural Ideology in the Case of Czech Punks and Skinheads. In THE SUBCULTURES NETWORK (eds.) Fight Back: Punk, Politics and Resistance. Manchester : Manchester University Press, 2014, pp. 170-185.

3 DANIEL, Ondřej. Násilím proti "novému biedermeieru". Subkultury a většinová společnost pozdního státního socialismu a postsocialismu. Příbram : Pistorius \& Olšanská, 2016.

4 CHARVÁT, Jan - KUŘíK, Bob (eds.) Mikrofon je naše bomba. Politika a subkultury mládeže v postsocialistickém Česku. Praha : Togga, 2018.
} 
has been no in-depth study of skinhead fanzines in the Czech context, although the topic has repeatedly appeared in the literature.

The topic is made even more impressive by the fact that a relatively large number of fanzines emerged from the Czech skinhead subculture, which contributed to forming the ideology of first-generation skinheads. They simultaneously reflected the subculture's ideological cleavages, including those within the far-right branch itself (disregarding anti-racist or apolitical fanzines). As the racist skinhead subculture formed in the first half of the 1990s, it split into more-or-less open neo-Nazis, on the one hand, and so-called Utraquist skinheads, with their ideological amalgam of nationalism, racism and authoritarianism, on the other. The Utraquist skinhead groups are a unique Czech phenomenon; they have no international counterparts and have thus far received minimal attention.

\section{Research question and methodology}

Therefore, the research question follows: In what ways are the publications of a selected neo-Nazi zine (Skinformátor, "The Skin-former") different from a selected representative of Utraquist zines (Kalich, "The Chalice")? In the following, I am going to focus on comparing the choice of topics and their elaboration in both fanzines. It is not the goal of this paper to analyse the different categories of fanzine content in depth. My goal at this research stage is to identify the contrasts between the two fanzines as representatives of different approaches to politicising the skinhead subculture in the far-right context.

As far as methodology is concerned, I proceeded in accordance with the principles of inductive thematic analysis. ${ }^{5}$ This method follows five steps, with the writing of the report itself as an additional sixth step. The first step involved getting acquainted with the texts of both fanzines. I started by initially inspecting each text and identifying the units of meaning. I then generated codes to determine the basic categories covering the different units of meaning. In the third step, I identified the main themes appearing in both fanzines. The fourth step consisted of "cleaning" the themes to avoid overlap. In practice, I re-read all the texts and corrected the ways the units were assigned to categories or subcategories. In the fifth step, I established the final main themes addressed by the fanzines and their internal structures in order to compare the two fanzines.

\section{Skinheads in Czechoslovakia and the Czech Republic}

The formation of the skinhead subculture in Czechoslovakia began in the second half of the 1980s, while the communist regime was still in place. A key role was played by the band Orlík, which emerged around the popular actors David Matásek and especially Daniel Landa, Orlík's lead singer. Founded in 1988, the band identified with the skinhead subculture and promoted a combination of (mainly)

5 BRAUN, Virginia - CLARKE, Victoria. Using Thematic Analysis in Psychology. In Qualitative Research in Psychology, 2006, Vol. 3, No. 2, pp. 77-101. 
Antiziganist racism, nationalism and anti-communism. ${ }^{6}$ This mix made Orlík extremely popular after the Velvet Revolution of 1989. A skinhead boom thus started after 1989 and lasted till approximately 1992, when it slowly came to a halt. The year 1993 saw the formation of the first official organisations based in this subculture (Vlastenecká fronta, Vlastenecká liga) as well as informal associations of an openly neo-Nazi nature (Bohemia Hammer Skins). ${ }^{7}$

As opposed to Western Europe's far-right, which had been forming for decades after WWII, the Czech far-right was rebuilt from zero after 1989. This is why the skinhead subculture and its racist part, in particular, won dominant status in the 1990s far-right. Apart from Miroslav Sládek's populist-right party and minority groups of Clerico-fascist orientation, the skinhead subculture was the only milieu that articulated its far-right ideology and political identity. ${ }^{8}$ In contrast to purely political projects, though, this milieu was able to inspire a large following, especially in the young generation. However, among its central issues were often rather a subcultural image, violence and White Power Music (also WPM). ${ }^{9}$ Racism was intrinsically linked to the skinhead identity and viewed as a natural part of the subcultural style (as demonstrated by one of the milieu's later leaders in his autobiographical amateur oral history). ${ }^{10}$

As such, the entire subculture became strongly politicised; politics itself became a subcultural attribute, indivisible from the skinhead identity as such (here I refer to the level of racist skinheads; other, non-racist skinhead groups emerged rather slowly and always represented a small minority within the subculture). ${ }^{11}$ This, however, does mean that the skinheads identified as political activists. The subculture members' relations to political engagement oscillated between acceptance (where the subculture acted somewhat as a political movement) and rejection (to return to the subcultural roots). ${ }^{12}$

The formative period was concluded by the establishment of a Czech branch of the international Hammer Skinheads organisation, the Bohemia Hammer Skinheads (BHS), which ultimately shifted the orientation of most Czech skinheads from the original Orlík-like racism to open neo-Nazism. ${ }^{13}$ The BHS was the most important Czech neo-Nazi skinhead organisation formed in the first half of the 1990s. It dates back to 1993 when it emerged around the long-term activists of the Czech

6 ORAVCOVÁ, Anna - CHARVÁT, Jan. Czech Rap Music and Right-Wing Attittudes. In Central European Journal of Politics, 2018, Vol. 4, No. 1, pp. 80-105.

7 MAZEL, Michal. Oponenti systému. In FIALA, Petr (ed.) Politický extremismus a radikalismus v České republice. Brno : Masarykova univerzita, 1998, p. 247.

8 DANIEL 2016; MAREŠ 2003.

9 More on the categories of White Power Music see CHARVÁT, Jan. The Role and Importance of White Power Music in Shaping the Far Right in the Czech Republic. In BLÜML, Jan - KAJANOVÁ Yvetta - RITTER, Rüdiger (eds.) Popular Music in Communist and Post-Communist Europe. Berlin : Peter Lang, 2019, pp. 243-253.

10 VÁVRA, Filip. Těžký boty to vyřešej hned! - Skinheads v Praze na konci 80. a začátku 90. let. Praha : Fiva Publishing, 2017.

11 MAREŠ 2003, p. 403.

12 CHARVÁT 2007.

13 MAZEL 1998, p. 247. 
neo-Nazi scene. ${ }^{14}$ From the beginning, it identified as an activist, elite and militant group rejecting traditional political activities (parties and elections) and oriented towards a "white revolution".

After several racially motivated skinhead attacks that resulted in bloodshed, the Czech police began combating neo-Nazi groups more vigorously around 1995. During the 1990s, BHS activities were monitored and subsequently dispersed by the police. The police also eliminated a network of post office boxes through which fanzines were distributed. Some leading activists were incarcerated, and others receded into the background and started "normal" lives. By around 1996, the BHS organisation was practically inactive. ${ }^{15}$ Czechia's most important neo-Nazi skinhead organisation of its time, BHS, took on a paramilitary appearance and at the same time openly adored National Socialism. Its organisation was centred in Brno and Moravia at large.

So-called Utraquistism was a specific orientation that emerged in the context of Czech far-right skinheads. ${ }^{16}$ The Utraquists followed the music of Orlík, whose lyrics promoted a patriotic and anti-communist skinhead identity, embraced Hussite traditionalism and rejected German Nazism. Although they relied on nationalism and racism, the Utraquists were against neo-Nazism and antisemitism. Registered with the Ministry of Interior in 1993, the Vlastenecká liga (VL) became the most crucial Utraquist skinhead organisation. In the mid-1990s, it grew to relative prominence and somewhat counterbalanced the openly neo-Nazi skinheads. It soon got into a major conflict with them. As a result, in 1996, the VL gave up the skinhead identity and instead embraced a purely political orientation in the future. However, this led to the gradual disintegration of the organisation and Utraquistism as a peculiar local variant of the skinhead subculture. After several attempts at resurrection, most of the organisation's activists left for apolitical skinheads or anti-racist skinheads (S.H.A.R.P.) on the one hand, and nationalist political organisations on the other. The subcultural framework seems to have played a significant role in bringing in new members and inspiring devotion among existing ones. ${ }^{17}$ In any case, Utraquistism was a relatively original contribution to the forms of skinhead subculture.

In addition to openly neo-Nazi publications, Utraquist skinheads produced their fanzines (Práče, which was the Hussite term for boy soldier; Český štít, "The Czech Shield"; and the Kalich), which followed-up on Orlík's original works and its specific interpretation of the Hussite tradition. ${ }^{18}$ While they especially accentuated patriotic and anti-German attitudes, they made no references to religious issues.

\footnotetext{
14 MAZEL 1998, p. 247.

15 MAREŠ 2003, p. 472.

16 MAZEL 1998, p. 260.

17 SLAČÁLEK, Ondřej-CHARVÁT,Jan. Setkávání na okrajových scénách. Průsečíky politického a subkulturního radikalismu v polistopadovém Česku. In Český lid, 2019, Vol. 106, No. 1, pp. 107-126.

18 SMOLÍK, Josef - NOVÁK, Petr. Roots of the Czechoslovak Skinheads: Development, Trends and Politics. In Human Affairs, 2019, Vol. 29, No. 2, pp. 157-173.
} 
They were typically affiliated with the VL as the officially registered organisation of mostly Utraquist skinheads. ${ }^{19}$

\section{Fanzines}

Stephen Duncombe's (1997) Notes from Underground: Zines and the Politics of Alternative Culture is perhaps the most seminal work of fanzine studies. The author provides the following definition: "Zines are non-commercial, nonprofessional, small-circulation magazines which their creators produce, publish and distribute by themselves". ${ }^{20}$ He notes that fanzines in the U.S. context can be traced back to the 1930s, albeit they proliferated, especially with the punk revolt of the 1970s. Duncombe argues that fanzines generally play a role in community building and are motivated culturally by the opportunity to present one's attitudes. Although he primarily focuses on fanzines in the alternative leftist scene, he also brings attention to neo-Nazi fanzines, characterising them as more political and pamphlet-like, with the primary goal of promoting an ideology. This is also supported by Kaja Marczewska's 2019 study of Polish far-right zines. She, too, argues that the fanzine culture is so deeply connected with and influenced by the punk revolt that most researchers assume all fanzines to be automatically alternative and leftist. "The punk heritage heavily informs the approach to cultural production represented in zines: zine publishing not only works outside of the market, it actively opposes its logic, working against the corporate media and the culture of late capitalism. As such, it is also implicitly associated with predominantly left-wing politics". ${ }^{21}$ However, she identifies the same principles underlying the operation of fanzines far-right and left-wing alike. The former contribute to unifying the far-right scene even when political propaganda recedes into the background: "These publications are now not a tool of propaganda and a means of communicating messages otherwise invisible in the mainstream, but rather a form of community building and inter-group association". ${ }^{22}$ Furthermore, she continues: "What emerges, then, from the pages of these zines, is a sense of collective and highly homogenous identity and a sense of a community that speaks in a unified voice". ${ }^{23}$

\section{Skinhead fanzines in the Czech Republic}

When the boom of the racist branch of the skinhead movement started in the early 1990s in Czechoslovakia, the initial ideology of Czech skinheads was primarily formulated and promoted by the mushrooming skinhead bands. It soon became apparent, though, that concerts alone could not satisfy the emerging subculture's demand for information. This resulted in the fast development of skinhead fan-

19 CHARVÁT 2007, p. 149

20 DUNCOMBE, Stephen. Notes from Underground: Zines and the Politics of Alternative Culture. London; New York : Verso, 1997, p. 11.

21 MARCZEWSKA, Kaja. Zine Publishing and the Polish Far Right. In FIELITZ, Maik - THURSTON, Nick (eds.) Post-Digital Cultures of the Far Right: Online Actions and Offline Consequences in Europe and the US. Bielefeld : transcript Verlag, 2019, pp. 107-119.

22 MARCZEWSKA 2019, p. 114.

23 MARCZEWSKA 2019, p. 115. 
zines. ${ }^{24}$ Established in the town of Žaclér in 1990, Hubert was the skinhead subculture's first fanzine. This type of publication assumed a central role in the gradual unification of the neo-Nazi movement. While bands continued to be tremendously valuable, the new fanzine medium won considerable support and many fans. This is because the concerts of neo-Nazi bands were relatively infrequent and expensive for most participants.

In contrast, fanzines were cheap and could be obtained through a network of relatively anonymous P.O. Boxes. As a result, they became central to the formation of new ideological patterns. ${ }^{25}$ For some time they served as the vital medium promoting the neo-Nazi ideology. The relatively short-lived "golden age" of Czech skinhead fanzines took place in the mid-1990s.

There was an extremely varying quality to the skinhead or, more precisely, neo-Nazi fanzines, ranging from genuinely do-it-yourself glued-together pages of photocopied text to relatively good-looking booklets with adequate graphic layout. Their contents were centred on authors' essays about contemporary society (especially on issues of the Roma, migrants and ideological enemies), pieces on history and mythology (typically adopted from official magazines) and band interviews. ${ }^{26}$ Due to their rigid uniformity, as described by Kaja Marczewska, interviews soon became the trademark of all neo-Nazi fanzines. Every interview included a set of near-compulsory questions like "What do you think about migrants, gipsies, communists..." or a positive version thereof such as "What do you think of the skinheads, BHS, National Socialism...". Publications like these were not difficult to make - a keen interest and essential equipment were all one needed. This is why several dozen zines appeared in the Czech territory during the first half of the 1990s. Their very titles spoke clearly: The Reich's Guard, The Aryan Fight, The Skinformátor, The Patriot, The National Fight. ${ }^{27}$

While the number of fanzine creators is hard to estimate, it seems from the composition of the articles that most collectives comprised of one or two principal authors and a small group, preferably in low units, of occasional correspondents. Therefore, the total number of individuals participating in the production of a single fanzine likely did not exceed five.

The second half of the 1990s marked the end of the early formative period of the skinhead subculture in Czech territory. Organisations were shut down and replaced by a new generation, one that also approached its media differently. The number of periodicals decreased considerably in the new millennium, while the quality improved. ${ }^{28}$ This can be exemplified by Phoenix, a magazine published by the Czech branch of Blood and Honour. This was the effect of the transfer of foreign know-how and the growing funds raised by the leaders

24 SMOLÍK - NOVÁK 2019.

25 MAREŠ 2003, p. 413.

26 SMOLÍK - NOVÁK 2019.

27 MAZEL 1998, p. 249.

28 SMOLÍK - NOVÁK 2019. 
of the neo-Nazi scene. Most printed fanzines were shut down around the year 2002 when media and propaganda moved online.

\section{The "Skinformátor"}

One of the most remarkable works of the racist branch of Czech skinheads, Skinformátor ("The Skin-informer") fanzine was published from 1994 to 1996, namely in the "golden age" of the country's National Socialist zines. A total of seven issues came out, making it one of the longest-lived zines with the highest number of individual publications. At the same time, the Skinformátor earned a very high number of media mentions (negative ones, which Czech neo-Nazis mostly did not mind), mostly due to its utterly explicit identification with the neo-Nazi ideology. This is what made the Skinformátor a role model for many other neo-Nazi zines. It is from this perspective that I view it as the ideal representative of the Czech neo-Nazi skinhead fanzine scene.

As a printed zine, the Skinformátor was distributed both at concerts and (like most other skinhead zines of the time) through a P. O. Box as its contact address. The P.O. Box was based in the North Bohemian city of Most. ${ }^{29}$ The region has long been struck by unemployment, and at the same time, it is home to many ghettos and a large Roma community. Due to this combination, the far-right in North Bohemia has been more successful than in other parts of the Czech Republic from the 1990 s to the present. ${ }^{30}$

As noted above, most skinhead zines were distributed through postal office boxes in the 1990s. This allowed their authors to remain anonymous. At the same time, the P.O. Boxes served to distribute music records, the other major element in the formation of the racist skinhead ideology. Interestingly, starting with No. 6, the Skinformátor postal office box also delivered the zine National Fight, based initially in the town of Bzenec. ${ }^{31}$ Edition No. 7 contained a notice that the zines Hlas krve (The Voice of Blood) and Impérium (The Empire) could also be purchased through the P.O. Box.

Likewise, starting with No. 6, the Skinformátor declared its affiliation with the Bohemia Hammer Skinheads organisation. ${ }^{32}$ Founded in $1995,{ }^{33}$ the BHS branch in the city of Most was probably associated with the Skinformátor's editorial circle.

\section{Content analysis}

In analysing the Skinformátor contents, I focused on several elements. My first goal was to identify the main themes addressed by the fanzine. Somewhat to my surprise, the list of themes was a concise one. The Skinformátor practically focu-

29 Salute kamarádi !!! In Skinfornátor, No. 2, p. 2.

30 VEJVODOVÁ, Petra. Neonacismus. In BASTL, Martin - MAREŠ, Miroslav - SMOLÍK, Josef - VEJVODOVÁ, Petra. Krajní pravice a krajní levice v ČR. Praha : Grada Publishing, 2011, p. 164.

31 Salute kamarádi !!! In Skinformátor, No. 6, p. 2.

32 In addition to the Skinformátor, the zines affiliated with BHS included the Patriot, The Hammer News, The White Rock Music, Nová Evropa ("the New Europe"), and the Skinhead Zone (MAZEL 1998, p. 249).

33 MAREŠ 2003, p. 471. 
sed on only four different areas of interest: White Power Music, the subculture/ movement, the enemies and something I refer to as "role models" - texts in the fourth category were concerned with historical models - Norse mythological figures and Hitler Nazis - and were used by the zine's authors to exemplify "appropriate actions" their readers should follow.

I should add that there were relatively frequent overlaps between the different categories. An article on Eric Banks, the singer of the U.S. band Bound For Glory, ${ }^{34}$ was categorised as related to WPM, but also contained a passage on enemies (accounting for a street fight in which Eric Banks died at the hands of anti-racist skinheads), and called for following his example, something that is rather an aspect of the movement. I proceeded in the analysis as follows: when there were multiple themes in an article, each of them was tagged separately (unless this was a minuscule mention). Therefore, the dataset contains more units than there are texts published in the fanzine.

In total, I identified 56 separate units of meaning in the Skinformátor fanzine. Twenty-five of them were categorised as White Power Music, 14 in the movement/subculture category, 14 in the enemies category, and three in the role models category.

The graph below makes it clear that White Power Music was the zine's leading issue by far - to little surprise when viewing zines primarily as fandom vehicles focusing on the realm of culture.

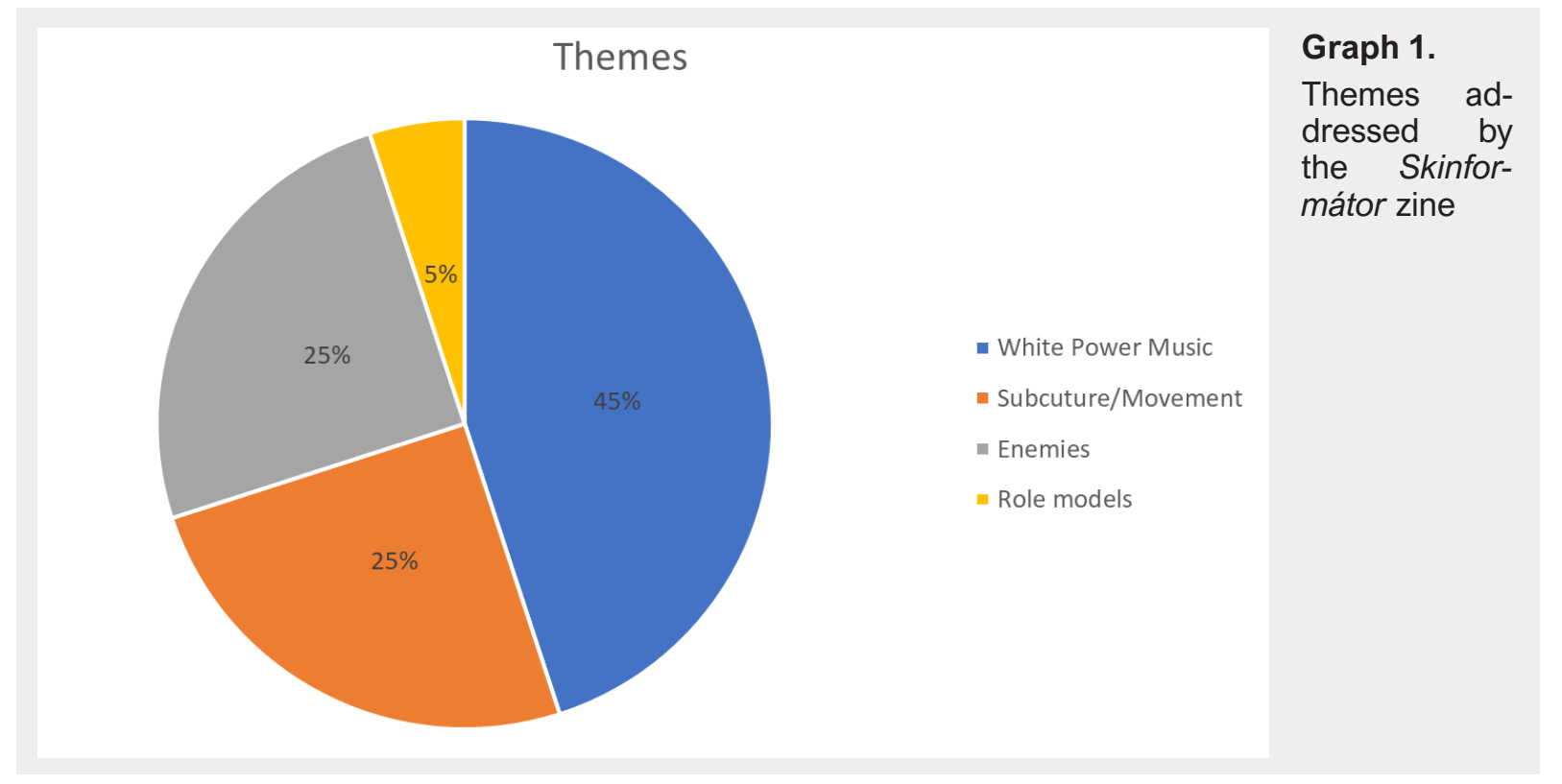

The themes categorised under White Power Music belonged to several distinct areas. First, there was information about concerts and reports from past concerts. The second group includes interviews with bands from the Czech Republic and abroad. Third, there is a relatively large number of advertisements for CDs

34 Erik Banks /1971 - 1993/. In Skinformátor, No. 6, p. 6. 
and the different bands' promotional merchandise. Finally, this category also includes regular charts of the most popular bands, both Czech and foreign. The texts reveal a relatively good acquaintance with the international WPM scene as well as contacts that the fanzine's authors were able to establish. This information was published for two general reasons. The first was social networking across the neo-Nazi scene. The second reason was to emphasise cultural capital and thus increase the zine's relevance in the eyes of its readers. From the third issue, the first acknowledgements referred to the German record company Di-AI Records. The acknowledgements in No. 7 were directed to the Italian bands ADL 122, Peggior Amico, and Corona Ferrera and the Polish band Konkwista 88. The concert reports, too, demonstrate the zine authors' ability to visit not only Czech and Slovak concerts but also outstanding concerts abroad.

The second category concerns texts informing about the skinhead subculture as such. Given the nature of the content included here, I instead opted for the label subculture/movement, because I believe that no clear line can be drawn between both concepts in the case of the 1990s Czech skinhead scene. From the moment the skinhead subculture entered the public space at the very beginning of the 1990s, most mass media referred to it as "the skinhead movement," and this has practically prevailed in the media discourse till the present day. Although some skinheads opposed the label at that time, most have adopted the term as their own, and, from the early 1990s, the Czech racist skinhead milieu has viewed itself as a movement rather than a subculture. Birmingham School researchers assumed that a subculture is comprised of working-class youth, and since it does not have a precisely formulated set of demands (it is indeed not used to this way of thinking), it uses symbols as its primary way of relating to political contents. ${ }^{35}$ This approach, however, does not fully apply to the Czech neo-Nazi skinhead milieu. Although the racist skinhead subculture in the Czech Republic after 1989 did predominantly consist of blue-collar youth, it always understood political agenda (albeit a highly schematic one) as a natural part of its subcultural activities.

Consequently, in the Skinformátor contents, political aspects are intertwined with subcultural ones, and they cannot be distinguished. As such, in most texts categorised as "subculture/movement," the references made to music or fashion are somewhat distant, and the political imperatives placed on the fanzine's readers play a much more critical role. More specifically, the authors make it clear how their readers should or should not behave. Such an approach might certainly also be acceptable in a subcultural arrangement, regarding norms rooted in the subcultural ideology, as described by Sarah Thornton ${ }^{36}$ or by the Czech authors Heřmanský and Novotná. ${ }^{37}$ However, it is rather a political rationale that frames

35 CLARKE, John - HALL, Stuart - JEFFERSON, Tony - ROBERTS, Brian. Subcultures, Cultures and Class. In HALL, Stuart - JEFFERSON, Tony (eds.) Resistance through Rituals. Youth Subcultures in Post-war Britain. $2^{\text {nd }}$ ed. London; New York : Routledge, 2006, pp. 3-59; KUŘIK, Bob - SLAČÁLEK, Ondřej - CHARVÁT, Jan. Roviny politizace ve výzkumu hudebních subkultur mládeže. In Sociologický časopis / Czech Sociological Review, 2018, Vol. 54, No. 5, pp. 781-804.

36 THORNTON, Sarah. Club Cultures: Music, Media and Subcultural Capital. Cambridge : Polity, 1995.

37 NOVOTNÁ - HEŘMANSKÝ 2014, pp. 170-185. 
the issue of skinhead behaviour in the Skinformátor. Its readers are admonished to act in line with their movement's needs, whereas the "Endsieg" of the white race represents the ultimate imperative. This approach appears in the article entitled, "Think about It", where the author talks about his disgust at some skinheads' behaviour during an Independence Day rally in Prague. According to the author, their actions were caused by their low political and moral consciousness and reflected poorly on the entire skinhead movement. Likewise, the articles about Eric Banks and Ian Stuart ${ }^{38}$ frame their life and death as a struggle for liberty and National Socialism. The article named "Support Our Common Goal"39 explains that readers should buy cassette tapes (instead of recording their copies from friends) in order to be one step closer to the joint victory. In the same issue, the text entitled "Are We United?" again explains the need for unity by appealing to the everyday struggle and the sacred racial war.

At the same time, there is an almost complete absence of texts on the history or characteristics of the skinhead subculture. Interestingly, the only complete reprint that appeared in the Skinformátor was an article named "How Oi! Lived and Died in the Lands of the Czech Crown" by Jiří X. Doležal ${ }^{40}$ of Reflex magazine. However, this article made no references to the history of the skinhead subculture or the role of black musicians in shaping the early stage of the subculture in 1960 s England.

The texts in this category emphasise political activities and their consequences. Directly speaking, the Skinformátor never examines how to be "a good skinhead" and instead is concerned with being "a good National Socialist," which is in line with the self-concept mentioned above of a movement rather than a subculture.

The terminology applied is consistent with this. The term "movement" appeared as early as in the introductory article of No. $3,{ }^{41}$ and then again in a concert report from the village of Velký Dřevíčc ${ }^{22}$ Likewise, it is mentioned in the last issue, namely its opening article ${ }^{43}$ and another article entitled "Are We United?". ${ }^{4}$ There is no single mention of the term subculture in the zine. Two instances of the term "scene" appear in a short text on Eric Banks ${ }^{45}$ and an advertisement on Vlajka's record Skin'n'Roll ${ }^{46}$ - both texts are exclusively concerned with music, in which context the word scene is a matter-of-course. At the same time, the issue of the movement is intertwined with the category of enemies presented by the Skinformátor. This category includes 14 units referring to groups against which the zine's authors take a stance.

38 Erik Banks /1971 - 1993/. In Skinformátor, No. 6, p. 6; Ian Stuart. In Skinformátor, No. 6, p. 7-8.

39 Podporujte náš společný cíl. In Skinformátor, No. 7, p. 3.

40 In the early 1990s, the journalist Jiří X. Doležal spent some time frequenting and taking an interest in the Prague skinhead milieu. Therefore, he was at least partially acceptable to the skinheads at that time.

41 Bílý opdor!!! 50 let. In Skinformátor, No. 3, p. 2.

42 Velký Dřevíč 26. 11. 1994. In Skinformátor, No. 3, p. 7.

43 Skinformátor, No. 7, p. 2.

44 Jsme jednotní? In Skinformátor, No. 7, p. 4.

45 Erik Banks /1971-1993/. In Skinformátor, No. 6, p. 6.

46 CD. In Skinformátor, No. 6, p. 19. 


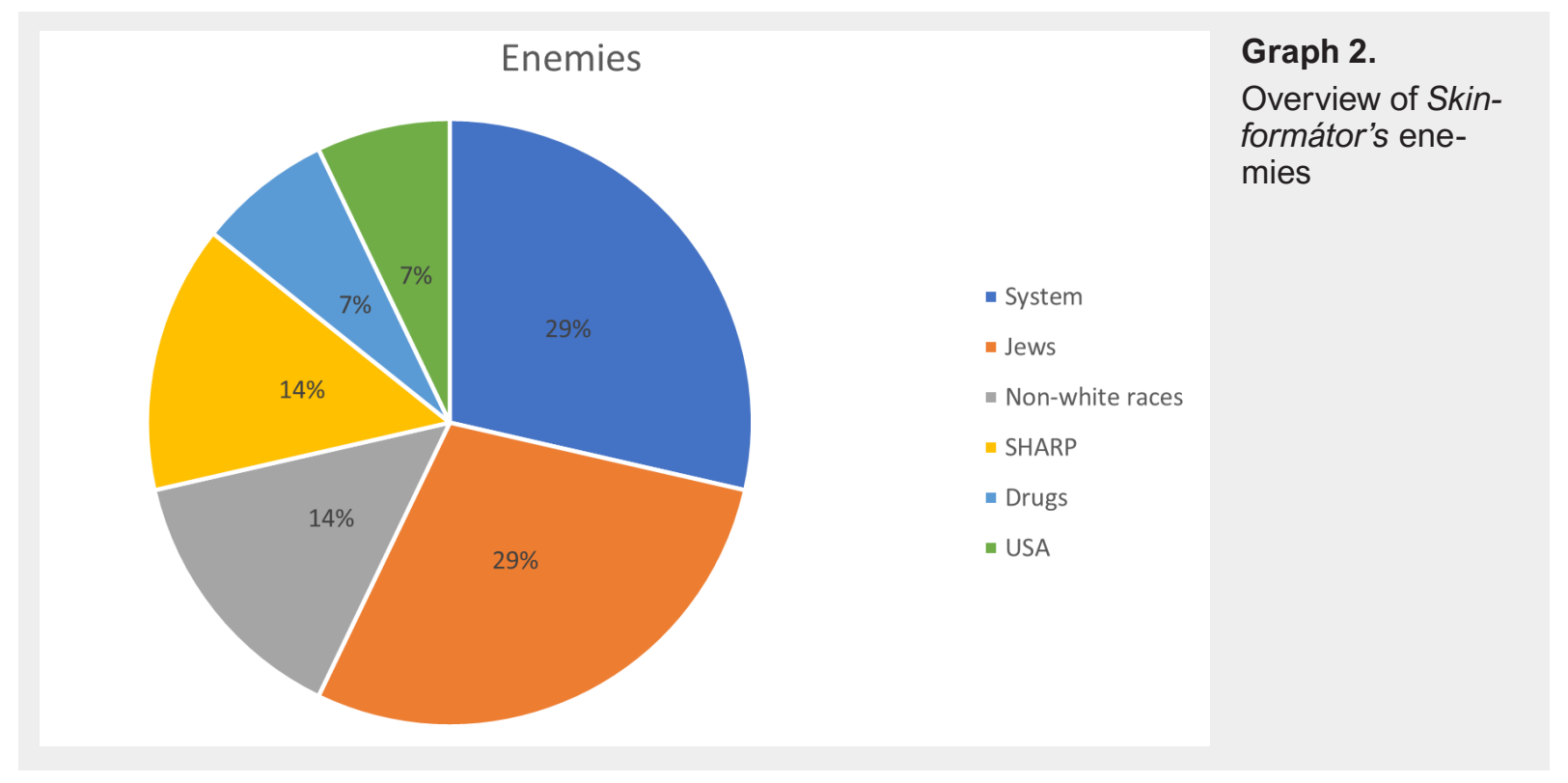

The analysis uses the label "system" for the first group of enemies, which encompasses almost one-third of the entire category. This includes texts against the media and the police (very traditional foes of the skinhead subculture irrespective of political affiliation or country), and I also opted to include an article entitled "Where Is Our Youth Going?", ${ }^{47}$ in which the author reflects on the situation of the youth in general and argues that it is exposed to the influence of U.S. television, Zionism and drugs. He provides a kind of catalogue of enemies who all have in common the problematic fact of being promoted by the media in contemporary society. Another article that focuses exclusively on the media, then deals with the effects of the media and the American lifestyle.

Jews represent the second category of enemies. Using a peculiar shorthand, the Skinformátor talks about Jews as "embodiment of the world's greatest filth". ${ }^{48}$ The entire text is highly schematic and, as opposed to one on the Vietnamese (see below), it lacks any real account based on personal experience, however, distorted that might be. Jews are also mentioned in interviews or with regard to the country's first commercial TV station, Nova.

The third group of enemies is defined in racial terms and includes the Vietnamese in particular. There was the option to merge both racially defined categories, namely racism, and antisemitism. However, latent racism towards the Roma and the Vietnamese was relatively commonplace in the 1990s society while open antisemitism was highly exceptional. That is the reason why I kept the two categories separate. In any case, if they were to be merged, they would comprise the largest group of enemies of all. The Skinformátor criticises the Vietnamese for being wealthy, for attacking Czechs, but especially for having relations with Czech girls, something referred to by the zine as "the crime of collaborationism

47 Kam směřuje dnešní mládež? In Skinformátor, No. 2, pp. 9-10.

48 Žid - škůdce naší rasy. In Skinformátor, No. 2, p. 5. 
and racial mixing" ${ }^{49}$ Other texts generally talk about racism as a doctrine that is essential to National Socialism and the survival of the white race.

Anti-racist skinheads (S.H.A.R.P.) represent the last principal subcategory of enemies. In the texts analysed, this relatively small segment was targeted by a considerable level of hate, which is in line with other evidence as well. ${ }^{50}$

Drug users and the U.S.A. were the remaining groups of enemies. Drugs symbolise the complete loss of control over one's life and are viewed as a consequence of following televised (American) role models. Finally, the United States is perceived as a symbol of decadence.

The last category, with three articles, includes imagined (historic) role models. Two such texts are concerned with Viking history, and one glorifies the Second World War. Both articles on Norse legends are devoted exclusively to that topic, mixing admiration of heroism with an intent to extend the political program to include a quasi-religious dimension. The text remembering WWII once again emphasises heroism and, at the same time, calls on contemporary Nazi followers to draw links between history and their current activities.

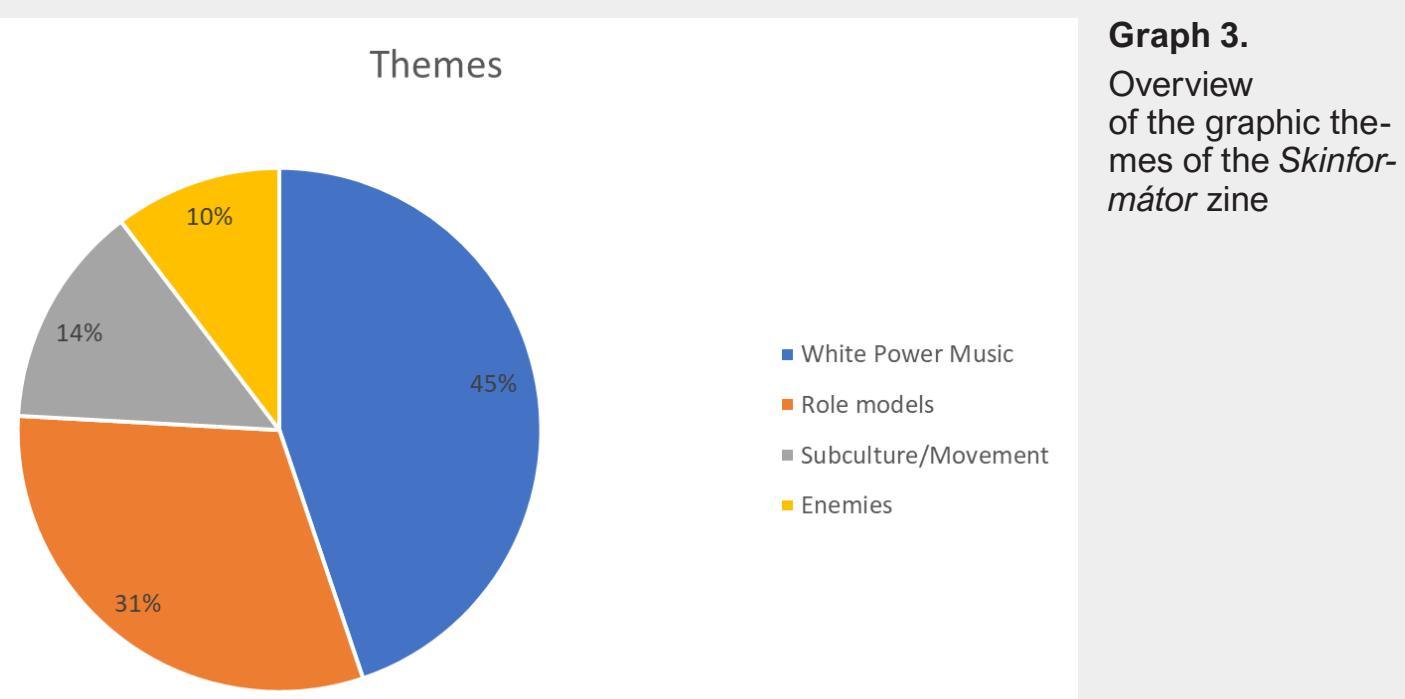

The graphic layout was the last aspect of the Skinformátor zine that I analysed. For skinhead zines, imagery generally plays a role at least as important as texts, and this case is no exception. The graphic themes can be divided into the same categories as the textual ones, namely White Power Music, role models, subculture/movement and enemies.

Logically, the largest category is comprised of WPM-themed images, above all concert photos and record covers. The category of role models exhibits highly similar

49 Yellow submarines. In Skinformátor, No. 2, p. 6.

50 For more details, CHARVÁT - KUŘÍK 2018. 
themes, as in the case of texts. Pictures of Viking warriors and gods are a popular motif, followed by Wehrmacht and SS officers and then Klansmen. Pronounced masculinity is a common denominator. The category of subculture/movement consists of subcultural symbolism and covers of fanzines reviewed or sold. The category of enemies reveals medical depictions (race) or antisemitic caricatures.

\section{The "Kalich"}

Utraquistism represents a specifically Czech variant of the skinhead subculture. It dates back to the late 1980s when Bohemia saw the inception of the Orlík band that openly identified with the skinhead subculture, incorporated open racism and nationalism in its lyrics, but strived to avoid associations with neo-Nazism and instead chose the $15^{\text {th }}$-century Hussite movement as its role model, a symbol referring to anti-German nationalism. A relatively outstanding early 1990s band, Orlík, also gave rise to the Vlastenecká liga, one of the officially registered organisations, in $1993 .{ }^{51}$

Several fanzines were published under the Patriot League. While the Czech Shield was perhaps the most popular, it gradually became a rather standard magazine focusing on organisational matters of the VL itself. As such, it was not suitable for my purposes. Besides, several Utraquist skinhead fanzines were published in association with the VL, of which the Kalich was the most important one.

A total of seven issues of the Kalich were published in the years 1994 - 1995. It thus belonged to the same period and encompassed the same number of issues as the Skinformátor. The fanzine was first distributed from a residential address and then, starting with No. 3, through a post office box, as was the custom at the time. The Kalich was published in the town of Jičín and directly associated with the local branch of the VL. The final, sixth issue stated the disintegration of the local VL organisation as the reason for shutting down the fanzine.

As opposed to the Skinformátor, more in-depth networking did not appear until the fifth issue, which ran ads for four other Utraquist fanzines. Acknowledgements, a natural part of most neo-Nazi zines, also appeared rather sporadically in the Kalich and typically were entirely personal, without obvious subcultural implications. As an exception, the final issue ran a more significant number of greetings and acknowledgements.

\section{Content analysis}

As in the case of the Skinformátor, I focused on the critical areas covered by the Kalich. The results were somewhat dissimilar. The categories were slightly more numerous, broader in coverage and different in weight. I identified five separate categories, yet most of them contained certain subthemes.

I proceeded in the same way as with the Skinformátor fanzine: when a Kalich article covered several themes, each of them was tagged separately. Thus, the dataset once again contains more units than there were texts published in the fanzine.

51 MAZEL 1998, p. 260. 
The Kalich dataset contains a total of 78 separate units that I worked with. The category of enemies includes 31 texts, the categories of role models and politics 15 each; there were 11 texts categorised as music and six as subculture/movement.

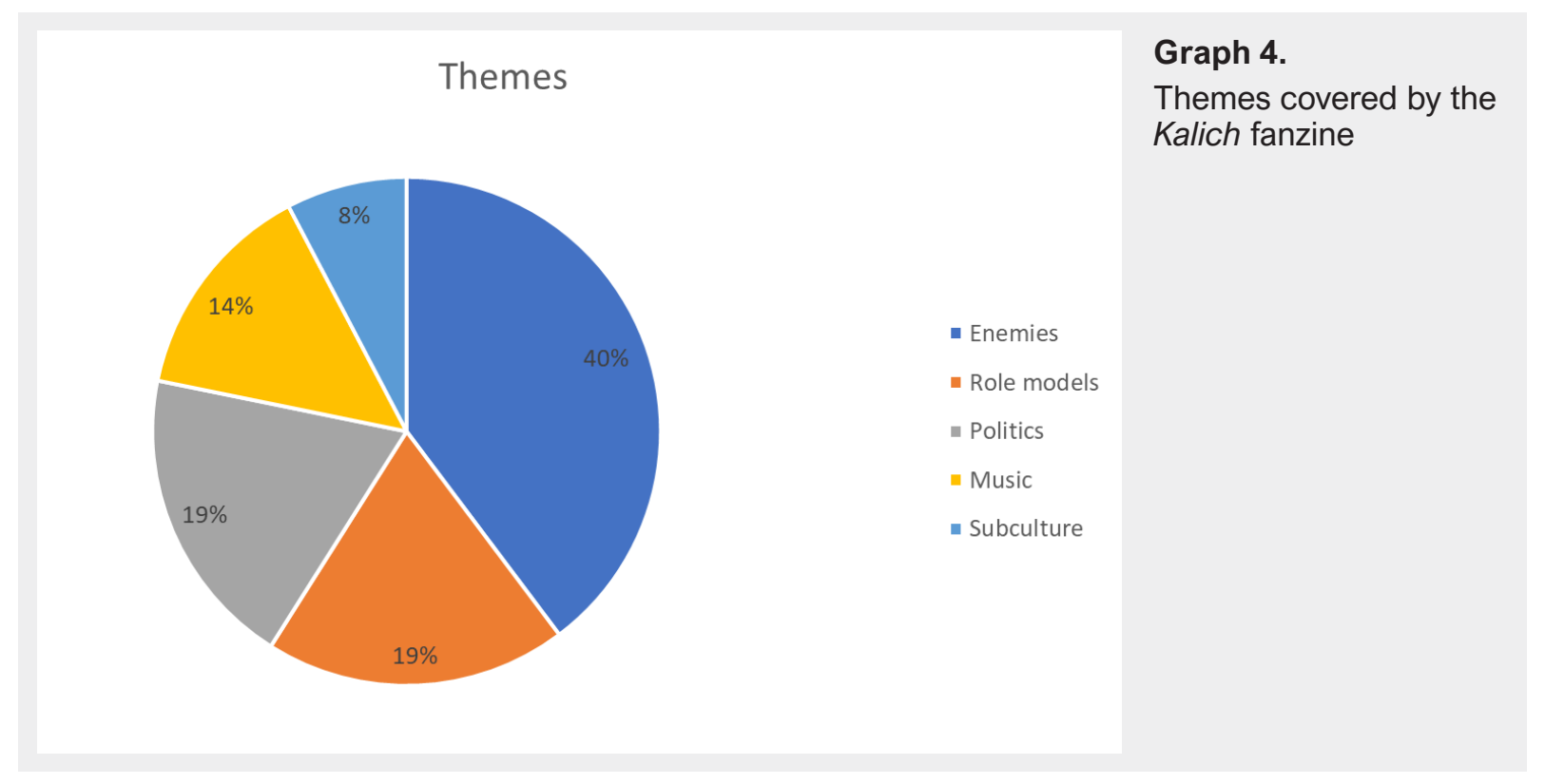

As can be seen, the distribution of themes differs considerably from the Skinformátor zine, and there are also differences within the categories. The second most relevant category, role models, includes a series of texts on historical events and leaders, mostly ones related to the Hussite movement (an article on Forefather Čech, founder of the Czech nation, in issue No. 1, is the only text not concerned with Hussitism). Like in the Skinformátor case, role models are identified in history, yet they are of a completely different origin. In addition to general texts on Hussite history, this category includes several articles focusing on John Hus, Jan Žižka, Jan Roháč z Dubé, and Prokop Holý, i.e., the most prominent leaders of the Hussite movement. The Kalich is also characterised by a series of articles on the Hussite traditions of different Czech cities.

The category of politics includes several texts about past rallies and additionally a broad range of articles on topics such as Czech nationalism, celebrations of the end of WWII and a Česká liga (Czech League) leaflet with many racist passages. Numerous attacks against neo-Nazi skinheads and fascism, in general, are one of the Kalich trademarks. This confusion (resistance against fascism while using racism) foreshadows the internal conflicts that became fatal to the Patriot League and were a general characteristic of the early 1990s and the formation of the Czech Republic's skinhead subculture.

The category of skinhead music is much less salient in this zine than in the case of the Skinformátor. However, the explanation is relatively straightforward: Utraquist skinheads were not affiliated with such a wide range of bands from all over the world as the White Power Music scene. Only four bands practically appeared in the Kalich: Orlík, Braník, Valašská liga (The Wallachian League) and solo music of Orlík's former 
singer Daniel Landa. The popular Top Ten and band charts also appeared here, like in the neo-Nazi zines, yet they were relatively poorly populated and relegated to the last pages by the editors.

In contrast to the Skinformátor, a relatively large body of texts is devoted to issues of the subculture itself. This, too, can be explained by the fact that Utraquist skinheads always struggled to negotiate their position within the subcultural pantheon of the 1990s Czech youth. Their skinhead appearance alienated them from punks and anarchists, while their Utraquist orientation made them race traitors in the eyes of the mainstream neo-Nazi skinheads. Moreover, the Patriot League itself sought to present itself as a political organisation resting unequivocally on Czech nationalism and, at the same time, clearly rejecting neo-Nazism. Due to the pressure produced by this combination, the zine's authors made repeated efforts to explain the history of the skinheads and draw a sharp line between neo-Nazis and Utraquists. This motif is also reflected in the shared narrative of these texts, namely that the early 1990s were marked by skinhead unity, whereas the present (i.e., the mid-1990s) was instead a time of quarrels.

This is generally also associated with the broadest category of enemies. As mentioned above, the Utraquist skinheads had an abundance of those.

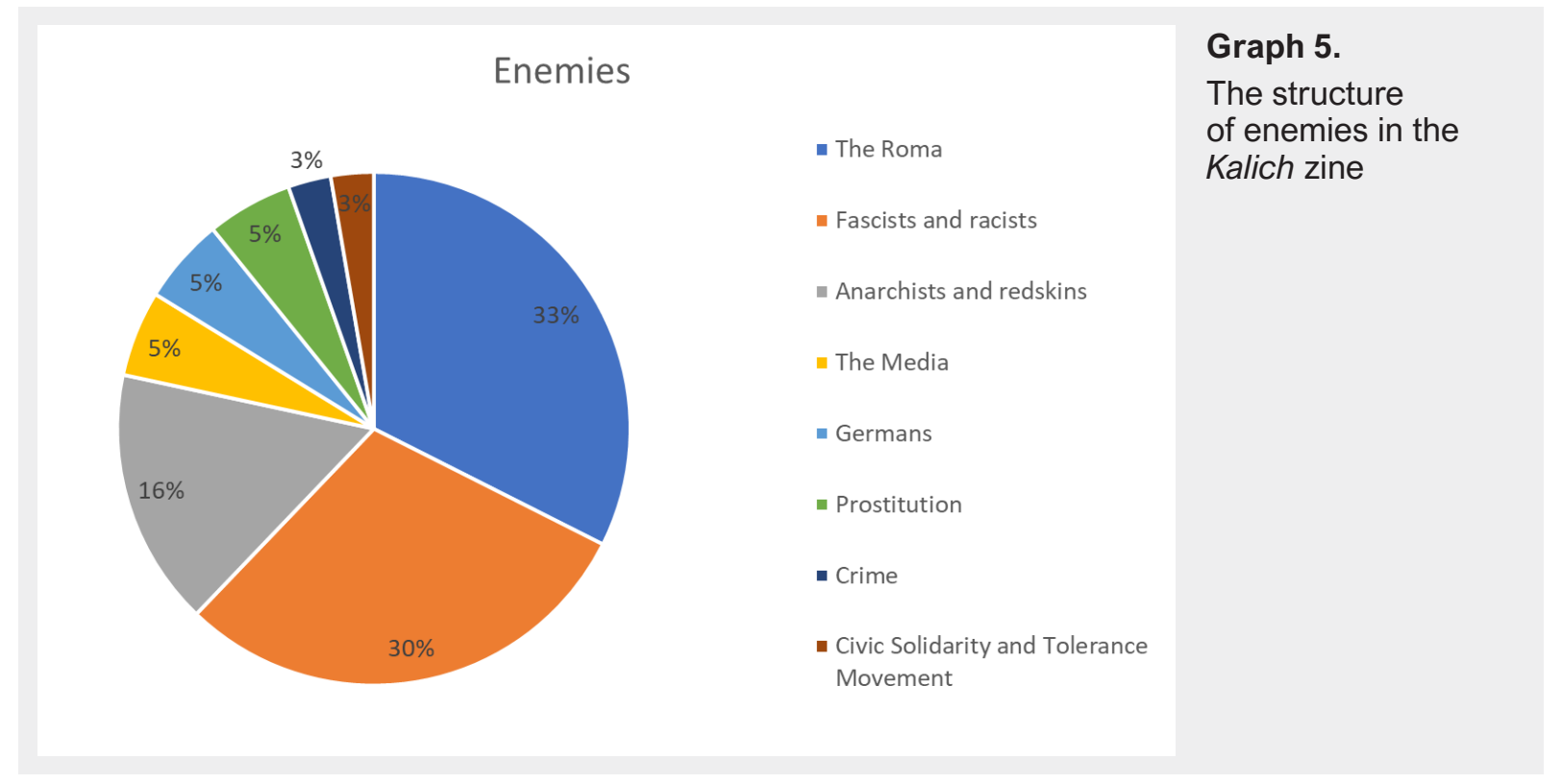

Once again, there are substantial differences from the enemies addressed by the Skinformátor. While the list is entirely devoid of Jewish people, it is topped by the Roma people, who were absent in the case of the Skinformátor. Political foes from both sides of the political spectrum combined represent the most significant part of the Utraquist skinheads' enemies - a perfect manifestation of the subcultural reality of the early 1990s Czech cities described above. 
"Out-of-control Roma crime" ${ }^{\prime 52}$ is the primary reason for Kalich's authors' grudge against the Roma population. At the same time, they reproduce the traditional racist clichés ${ }^{53}$ of low IQ and incestuous relationships. However, the solution is not "...apartheid but to make laws apply to everyone and protect everyone". ${ }^{54}$

Their criticism of political enemies differs by political orientation. The neo-Nazis and fascists are criticised primarily for following an ideology that previously led to the occupation of Czechia and executions of Czech patriots; the German origin of the ideology is also emphasised in some instances. Secondarily, neo-Nazis are blamed for undermining the unity of nationalist skinheads. Anarchists and redskins are mainly criticised for their affiliation with the far left. Across the board, neo-Nazi skinheads, redskins and anarchists are depicted as fools that do not know the history or are under the influence of drugs (anarchists).

In contrast, criticism of the media is consistent with the Skinformátor. The Kalich blames them for lying and mistaking the Utraquists for neo-Nazis. ${ }^{55}$ The authors argue that this is because the journalists in question worked in the media before 1989, and as such, they were formed by their communist experience.

In the tradition of Orlík-like anti-German chauvinism, there are attacks against Germans that emphasise their perceived role as a "fifth column"56 and their historical responsibility for unleashing the Second World War.

Prostitution and crime are criticised as sources of increased security concerns. A specific enemy, the human rights organisation HOST (Civic Solidarity and Tolerance Movement), was targeted by the Utraquists due to the Patriot League's lawsuit against it. This criticism focused primarily on the HOST's failure to distinguish between Utraquist and neo-Nazi skinheads.

In the case of the Kalich, too, the graphic layout is the last thematic category. The fanzine's imagery is again relatively essential and there is a large number of pictures in the publication.

As the graph reveals, role models represent the critical category of imagery, consisting of numerous Hussite-themed depictions. Combinations of Hussite symbols and the Celtic cross are no exception. Despite being a far-right symbol, the Celtic cross is characteristic of the Utraquist skinheads. In the absence of explicit mention in the fanzine, one can assume that the Celtic cross was perceived as a universal skinhead symbol, not a symbolic replacement of the swastika as neo-Nazi skinheads used it. In the Czech context, this symbol was popularised by Orlík, which was viewed as an Utraquist band.

52 Násilí kolem nás. In Kalich, No. 1, p. 14.

53 Démonizace. In Kalich, No. 2, p. 14.

54 Romská kriminalita. In Kalich, No. 4, p. 4.

55 Televize - oči národa. In Kalich, No. 3, p. 5.

56 Čeští vlastenci. In Kalich, No. 4, p. 21. 


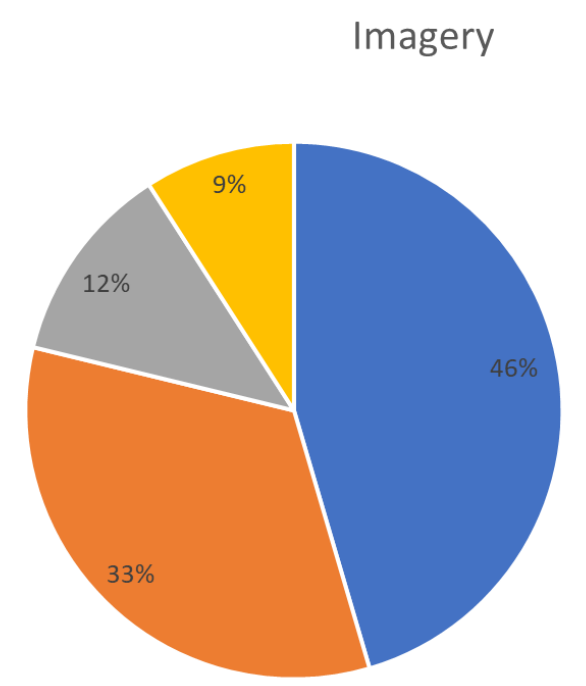

Graph 6.

Imagery of the zine Kalich
- Role Models

- Subculture

- National symbols

- Enemies

The subcultural imagery includes both photographs from concerts and drawings of skinheads. Like in the Skinformátor, there is a general absence of female figures, and the overall imagery is highly masculine, albeit to a lesser extent than in the Skinformátor case.

National symbols come as a little surprise, as they indeed can be expected of an Utraquist fanzine. Depictions of enemies mostly take the form of photographs attached to texts on political opponents. The Skinformátor's usual racist caricatures are absent.

\section{Conclusion}

What exactly did the analysis of both fanzines reveal? While some aspects are relatively predictable, others appear as somewhat surprising. Let us start with the predictable ones. It is hardly perplexing that White Power Music is a crucial component of a neo-Nazi fanzine to the extent that an Utraquist fanzine cannot match. The explanation is obvious. The Utraquist scene was not integrated with the international White Power scene, and as such, it necessarily treated music as a marginal affair. Relatedly, the Skinformátor placed a much stronger emphasis on social networking and the ensuing accumulation of subcultural capital. This aspect perhaps suggested the neo-Nazis' outward orientation, their ambition to connect their activities to other likeminded groups and build a broad, international movement. At the same time, the Utraquists were typically inward-looking in terms of both their scene and their own country. The accent on Czech history is formidable in the Kalich and utterly absent in the Skinformátor. Given the local origin of Utraquist skinheads and their emphasis on Czech traditions, one might assume that this part of the subculture was destined for prosperity, yet the exact opposite was the case.

There is an exciting difference in historic focus between both fanzines. Each of them relates to history in its way - and relates to a different history. Whereas the Kalich paid extensive attention to the Hussite traditions of Czech cities and another key 
theme, the historical figures of the Hussite movement, the Skinformátor aimed at Germanic mythology as well as Wehrmacht soldiers. The Skinformátor practically openly admitted that its historical tradition was in no way related to Czech history or mostly to history at all. The fact that its critical texts in the category of role models referred to imaginary figures of the Viking pantheon helps us realise that rather than upon history, its view was centred on mythological fantasy, one which bolstered the cult of heroes that had been so popular in historic Nazism already.

Furthermore, allow me one last note on history. It again comes as a little surprise that the Skinformátor did not publish any in-depth text on the history of the skinhead subculture itself, while several such articles can be found in the Kalich. Neo-Nazi skinheads found the links between the early skinhead subculture and black music to be highly problematic and avoided them, although they were aware of them (for example, the zine Hubert, mentioned above, wrote about the role of ska and reggae at the roots of the skinheads). The tradition they related to did not date back to 1969 but, metaphorically speaking, to 1988. My point here is that the historical origins of the subculture were irrelevant to Czech neo-Nazi skinheads because, in their eyes, it was their experience of the late 1980s and early 1990s skinhead scene, with its utterly racist and often neo-Nazi orientation, that counted as actual (real) history. Most Czech White Power bands took a similar position on the subculture's history. ${ }^{57}$ In contrast, the particular experience of the Utraquist skinheads was derived from their history of negotiating one's position in clear distinction from the neo-Nazis. As a result, they paid much more attention to subcultural history and also attempted to reproduce it on the pages of their fanzine.

The Skinformátor elaborated subcultural themes to a much lesser extent. By the mid1990s, the racist skinhead subculture seemed to be relatively clearly established, and there was no more need for lengthy explanations of who is a proper skinhead or what he should look like. The new fundamental question was how a proper National Socialist should behave. Moreover, the zine's authors made it relatively clear that the "Endsieg" of the white race was the key imperative. It was against this goal that one's actions were to be measured. No such imperative can be found in the Kalich, despite the presence of political attitudes. Those are, however, aimed at the conservative defence of nationalism and "law and order," not a vision of a "white (or any other) revolution".

Some aspects of the enemy theme addressed by both fanzines are also somewhat predictable. The media, typically represented by the duo of TV Nova and the Blesk daily, were considered enemies by both fanzines as they symbolised the "tabloid" nature of the media universe. This is a traditional part of the repertoire of skinhead subcultures irrespective of political affiliation. It is similarly unsurprising that the police are absent from the Kalich's list of enemies. Hatred for the police would have damaged the reputation of the Utraquists, led by the Patriot League, as they tried to present themselves as an acceptable political alternative.

57 CHARVÁT 2018. 
Moreover, as expected, the Utraquist fanzine did not mention antisemitic issues while the neo-Nazi one did - albeit the Skinformátor's candour in this regard may be eye-opening. In contrast, it comes as a relatively big surprise that the traditional (and predictable) hatred for the Roma community was absent from the Skinformátor, yet it dominated the Utraquists' category of racially defined enemies. This may be because of the belief, as presented in the Skinformátor itself, that Jews are the real root of all evil, and they are merely using every other minority. Albeit the declared grudge against the Vietnamese somewhat contradicts this view, this can be explained, as suggested explicitly in the text, as a grudge against racial mixing. The same aspect cannot be found in the Utraquist zine, which explicitly states that problems with the Roma should be solved by strict compliance with the law.

Both fanzines agree that drugs are one of the problems of modern society and youth in particular - along with foreign influences. They differ only insofar as the Skinformátor presents the U.S. as the greatest source of problems, while for the Utraquists it is Germany.

Thus, the two fanzines represent two different faces of the Czech subcultural far right. The Skinformátor represents a kind of open neo-Nazism that only adopts such aspects of the skinhead subculture that it needs, primarily the masculine paramilitary appearance, and infuses it with mostly political contents oriented towards the envisioned revolution. In contrast, the Utraquists represent a more conservative and less revolutionary element that aims at law and order. I believe that both cases are relevant representatives of their respective categories, and an analysis of other fanzines of the neo-Nazi or Utraquist orientations would yield similar results. To sum up my account, I have observed a confident and ambitious neo-Nazi movement rooted in the international White Power scene and relying on a quasi-religious symbolism with a clear view to waging a "racial holy war", vis-a-vis the defensive Utraquists with their narrow orientation on domestic history, balancing between political enemies and pampering their idols, led by Daniel Landa.

Cituj:

CHARVÁT, Jan. "'Tis with the Chalice that We'll Defend Our Country against the Cross..." Analyzing and Comparing the Contents of Neo-Nazi Fanzine Skinformátor and Utraquist Zine Kalich. In Forum Historiae, 2020, Vol. 14, No. 1, s. 84-102. ISSN 1337-6861. DOI: https://doi.org/10.31577/ forhist.2020.14.1.7

Mgr. Jan Charvát, Ph.D.

Institut politologických studií, Katedra politologie

Fakulta sociálních věd Univerzity Karlovy

U Kríže 8

15800 Praha 5, Česká republika

E-mail: charvatj@centrum.cz 